TAPROBANICA, ISSN 1800-427X. December, 2013. Vol. 05, No. 02: pp. 120-123.

(C) Taprobanica Private Limited, 146, Kendalanda, Homagama, Sri Lanka.

http://www.sljol.info/index.php/tapro

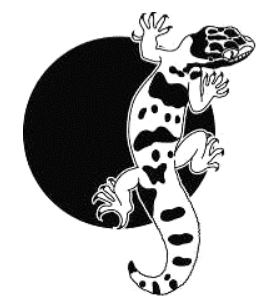

\title{
A NEW ORCHID OF THE GENUS Bulbophyllum (ORCHIDACEAE) FROM WESTERN GHATS OF SOUTHERN INDIA
}

${ }^{1}$ Department of Botany, Centre for Botanical Research, The Madura College (Autonomous), Madurai 625011, Tamil Nadu, India; Email: ksamytaxonomy@ gmail.com²

\begin{abstract}
Bulbophyllum aureoflavum, a new orchid from Western Ghats of southern India, is described and illustrated. The new species, Bulbophyllum aureoflavum, is rare and known presently only from the type locality in southern Western Ghats. This species is related to B. elegantulum and B. fischeri, but differs by having a thick rhizome, subglobose pseudopbulb, bendant filiform scape, and a light golden yellowish, glabrous flower.
\end{abstract}

Key words: Bulbophyllum aureoflavum, new species, pantropical, taxonomy.

\section{Introduction}

Bulbophyllum Thouars is one of the largest genera of orchids with over 1700 species distributed pantropically in the Old World (Dressler, 1993; Sieder et al., 2007; Chen et al., 2009). Bulbophyllum is the second largest angiosperm genus in India, represented by about 100 species with some 40 known from Western Ghats (Misra, 2007). The newly collected specimens are from the Munnar-Devicolam Range of Kerala State in southern Western Ghats. After critical examination, we found that the floral morphology differs from all other hitherto known species from India or even southeastern Asia. Consequently, we described it as a new species.

\section{Bulbophyllum aureoflavum Karuppusamy \&} Ravichandran, sp. nov. (Fig. 1, 2)

Type: Southern India, Kerala State, Munnar, on the road to Poopara near Gap Road, rare on shaded rocks $\left(10^{\circ} 02.127^{\prime} \mathrm{N}, \quad 77^{\circ} 08.256^{\prime} \mathrm{E}\right.$; alt. 1200m), 12 May 2011, S. Karuppusamy 1246 
(holo: $\mathrm{MH}$; iso: Sre Ganesan Herbarium at the Madura College), see Fig. $1 \& 2$.

Diagnosis: The species can be differentiated from its allied species only when flowering during the dry months of May and June. The species is easily overlooked because its small bulbs and leaves are similar to those of Bulbophyllum elegantulum J. J. Sm. and $B$. fischeri Seidenf. Bulbophyllum aureoflavum which can be distinguished by its long, filiform, pendent, 12-flowered scape and by its golden yellowish, elliptic, connate, glabrous, and lateral sepals. Haec species Bulbophyllum elegantulum et $B$. fischeri similes, rhizome crassis, pseudobulbis subglobosis, scapus filiformis, flores aureo-flavo, sepalum elongato-ovatum, labello profunde sulcate differt.

Description: Lithopyte, creeping, rhizomatous herb. Rhizome ca $0.3 \mathrm{~mm}$ diam thick, terete, clothed with brownish hairs. Pseudobulb $1.4 \times 1$ $\mathrm{cm}$, subglobose, brownish, $1.5-2.5 \mathrm{~cm}$ apart, molten shining, ribbed vertically, light greenish brown when immature. Leaf solitary; petiole short, $0.5 \mathrm{~mm}$ long, glabrous; blade ellipticovate, $5 \times 1.5 \mathrm{~cm}$ long, light to dark green, unequally notched apically. Scape solitary, arise from base of pseudobulb; peduncle longer than leaves, up to $6 \mathrm{~cm}$ long, filiform, glabrous. Bracts $3 \times 1 \mathrm{~mm}$, lanceolate, acute, minutely 3veined, glabrous. Inflorescence umbellate, 12flowered; pedicel up to $4 \mathrm{~mm}$ long, glabrous. Flowers light golden yellowish, fluorescent greenish in bud; dorsal sepal ovate-lanceolate, $0.7 \mathrm{~mm}$ long, minutely 3-veined, yellowish, glabrous, acuminate, hooded; lateral sepals membranous, $2 \times 0.7 \mathrm{~cm}$, obovoid-elliptic, transparent yellowish, inconspicuously 3-veined, connate along the dorsal margins; petals ovate, yellowish, 3-veined, glabrous, acuminate; lip prominent, $10 \mathrm{~mm}$ long, dialated basally; upper lip membranous, lanceolate, acuminate. Column boat-shaped, rectangular, ca $0.1 \mathrm{~mm}$ long; stigmatic lobes curved. Pollen mass two, attached on upper curve of stigma, bright yellow, minute, $0.1 \mathrm{~mm}$. Ovary $0.5 \mathrm{~mm}$ long, greenish, slightly ribbed, minutely pubescent. Fruit ovoid, $1 \mathrm{~cm}$ long, ribbed.

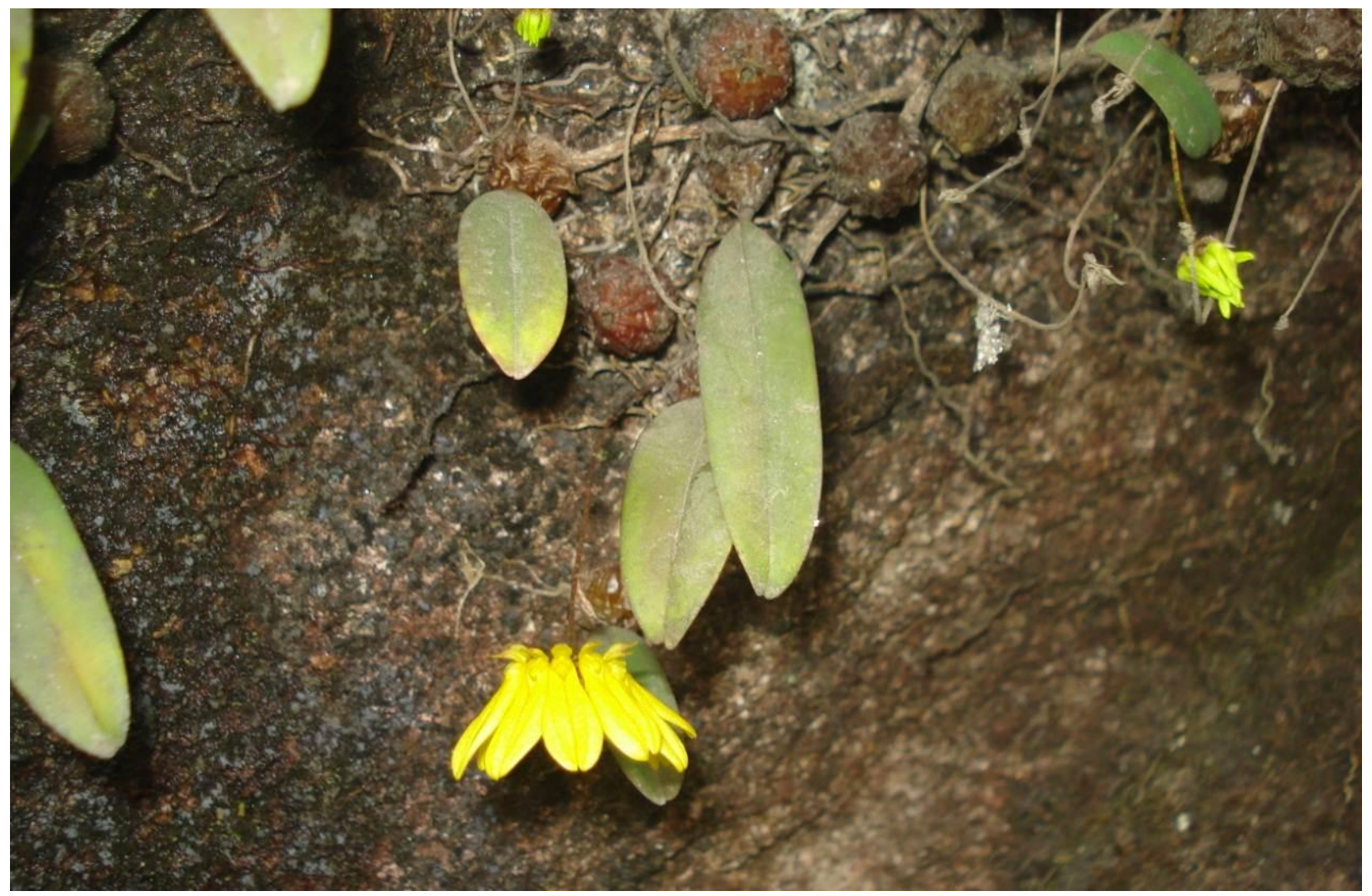

Figure 1: Habitat photograph of Bulbophyllum aureoflavum. 

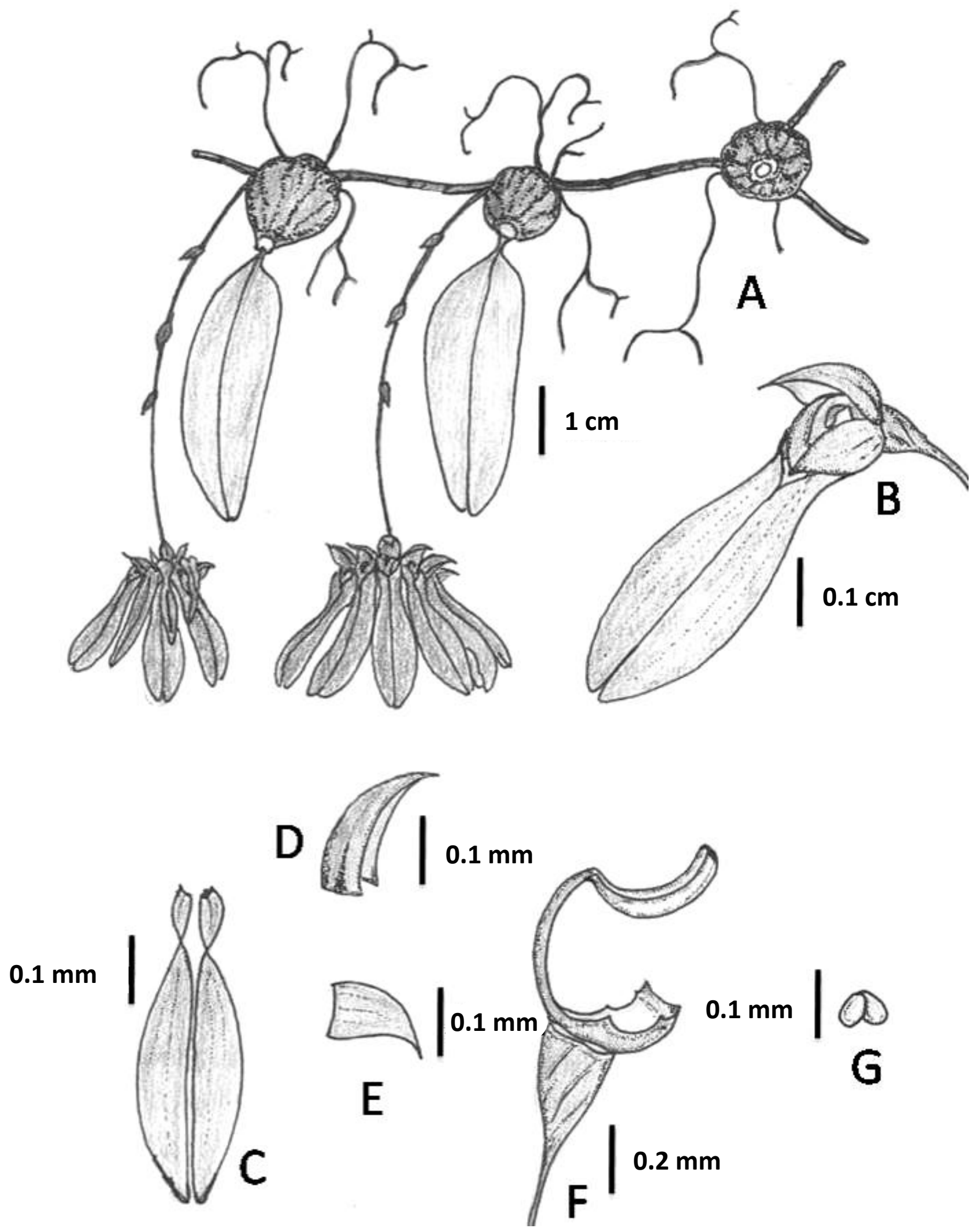

Figure 2: Bulbophyllum aureoflavum. A, habit; B, flower; C, lateral sepals; D, dorsal sepal; E, petal; F, ovary with column and lip; G, pollinia 
Flowering and Fruiting: May to August.

Distribution: Endemic to the Munnar-Devicolam Range of Western Ghats, Kerala State, India, growing on shaded rocks at about $1200 \mathrm{~m}$. It is known only from the type locality.

Remarks: The present study noticed only 15 well-separated clumps, each of no more than 100 bulbs on shaded rocks next to the road from Devicolam to Poopara.

Conservation status: Bulbophyllum aureoflavum has a restricted distribution and currently is known only from type locality in an area of about $10 \mathrm{~km}^{2}$ where represented by about 15 clump-like populations. Until further explorations determines its distribution range, biology and threats, the conservation status of the species cannot be assessed. However, the available information qualifies the new species as a critically endangered species although the data are deficient for a complete evaluation.

\section{Acknowledgements}

The authors are thankful to G. V. S. Murthy (Deputy Director of BSI, Southern Circle, Coimbatore), for providing herbarium consultancy and library facilities for confirming the identity of the new species.

\section{Literature Cited}

Chen, X. and J. J. Vermeulen, 2009. Bulbophyllum. Pp. 404-440. In: Flora of China, Volume 25 (Orchidaceae). http.//www.flora.huh.harvard.edu/ china/mss/volume25/FOC_25_Orchidaceae_all.pdf

Dressler, R. L., 1993, Phylogeny and classification of the orchid family. Dioscorides Press, Portland: 314.

Misra, S., 2007, Orchids of India. Bishen Singh Mehendrapal Singh, Dehra Dun: 402.

Sieder, A., H. Rainer and M. Kiehn, 2007. CITES checklist for Bulbophyllum and allied taxa (Orchidaceae). 319. Botanical Garden, University of Vienna. http.//www.cites.org/common/com/ NC/tax_ref/Bulbophyllum.pdf. 